\title{
Farmer Exchange Rate and Agricultural Land Conversion Analysis to Agricultural Sector Poverty in Indonesia
}

\author{
Indah Lestari Setiyowati, Sasongko, Iswan Noor \\ Master Program of Economics and Business, Brawijaya University \\ Email: indah.lestarisetiyowati@gmail.com
}

Received: June 14, 2017; Accepted: November 7, 2017; Published: February 2, 2018

Permalink/DOI: http://dx.doi.org/10.17977/um002v10i12018p035

\begin{abstract}
The agricultural sector poverty in Indonesia is affected by some factors like income and agricultural land area. Farmer exchange rate is an indicator of farmer welfare that can be a measurement of farmer real income. Farmer exchange rate tends to be increased from 2009 to 2013. Besides, the agricultural land area tends to decrease that time. Decreasing of agricultural land is caused by agricultural land usage conversion. This research aims to analyze direct and indirect effects of farmer exchange rate and agricultural land conversion toward agricultural sector poverty in Indonesia, with the objects of 33 provinces in Indonesia (excludes North Kalimantan) from 2009 until 2013. This research is using path analysis to obtain the result, with agricultural laborer variable and agricultural productivity as intervening variables. The result obtained that farmer exchange rate has a direct and indirect effect toward agricultural sector poverty, besides agricultural land conversion has an indirect effect toward agricultural sector poverty.
\end{abstract}

Keywords: Farmer Exchange Rate, Agricultural Land Conversion, Agricultural Productivity, Agricultural Sector Poverty

JEL Classification: I32, Q01, Q24

\section{INTRODUCTION}

Indonesia is an agrarian country where the majority of them still rely on agriculture sector as the main occupation. Agriculture sector contribution toward national GDP in 2004 up to 2009 reach around 13,9\% each year and undergoing improvement to be 14,9 percent on period 2012-2013. the increasing of nominal score donation on agriculture sector toward national GDP happened in 2012 approximately $\mathrm{Rp} 1.190,4$ billion rather than in 2005 which reach up to $\mathrm{Rp} 364,2$ billion (Bappenas, 2014). On the other hand, poverty contribution in agriculture sector is still big when it is compared with the non-agriculture sector, in 2013, poverty in agriculture sector reach $37,96 \%$ and the non-agricultural sector is $25,32 \%$ (BPS, 2014). It is affected by some aspects including the rate of low income and narrowing of farm land (Hasanuddin et al., 2009). Farmer's real income can be seen from how big the farmer exchange rate is (Syekh, 2013) which constitutes a ratio between price index accepted by the farmers and price index paid by them, commonly from the farmer exchange rate can be seen whether the farmers undergo the surplus or not. Farmer exchange score in Indonesia tends to be increased namely 100,16 in 2008 and is increased to 104,92 in 2013 (BPS, 2015). 
The land usage which is increased in non-agricultural sector keeps compelling the usage of agriculture land mostly in rural area, so the land usage shift will happen. According to Damayanthi (2008) the increase of population, the improvement of technology and agriculture will compel the needs of agriculture lands for non-agricultural activity. The phenomenon happened is land conversion which is caused by agricultural land shifting usage in Indonesia are increased drastically even though farmer exchange rate is indicatively increasing rapidly. The large of agricultural land in Indonesia has some tendencies to decline from year to year, in 2012 Indonesia has agricultural land which is 40.157 .738 hectare and keep declining into 39.475.694 hectare in 2013. Based on the facts this research has an aim to analyze direct and indirect effects on farmer exchange rate and agricultural land conversion to agricultural poverty in Indonesia.

The narrowness of land owned by farmers is largely due to the conversion of agricultural land, so conversion of agricultural land has a negative effect on the welfare of farmers (Danapriatna \& Panuntun, 2013). However, in this case, there is research inconsistency, where Munir (2008) finds that the conversion of agricultural land has a positive effect on the welfare of farm households in Candimulyo, Wonosobo, Central Java.

\section{LITERATURE REVIEW}

\section{Agricultural Poverty}

The vicious circle of poverty conducted by Nurske is mentioned that the lack of productivity is caused by some factors namely ignorance, market imperfection, and the lack of budget. Lack of productivity causes low income. Low income causes savings lacks, meanwhile, the low savings causes low invest. The lack of investment will affect the lack of budget, ignorance and so on so it can make some circle patterns which causes poverty (Kuncoro, 2010).

Poverty according to Nugroho \& Dahuri (2012) is an absolute condition or relative toward someone or society which is not capable to fulfill their basic needs according to the available norm in society caused of natural condition, cultural and structural. Poverty is a human condition which cannot fulfill the economic needs which is minimal needs from some living standard, so the poverty can be categorized into 2 sides namely (Kuncoro, 2010):

1. Absolute poverty is a poverty because of incapability to fulfill minimum basic needs, the measurement of absolute poverty which is based on the great total poor society that below the poverty line.

2. Relative poverty is a poverty because of incapability to fulfill live standard decided by surrounding society, it is closely related to the income distribution.

A citizen with poor categories is a citizen which have outcome per month below the poverty line (BPS, 2013). Poverty line determined by BPS constitutes a sum of food poverty line and nonfood poverty line. Meanwhile, the agricultural poverty is a citizen which work in the agricultural sector and stay below the poverty line.

\section{Farmer Exchange Rate}

Farmer exchange rate concepts developed by BPS is an exchange value concept with macro scale. Its concept measures the exchange value from commodity result produced by the farmer toward farmer outcome either for 
consumption or production budget. Basically, it constitutes the comparison between a price accepted and a price paid by farmers, but to describe farmer exchange rate between time, so the price accepted by farmers and the price paid by farmers is measured with index (Sadikin \& Subagyono, 2008):

where :

$$
I F E X=\frac{I A}{I P}
$$

IFEX : index of farmer exchange rate

IA : index of price accepted by farmers

IP : index of price paid by farmers

If farmer exchange rate has value above 100 means the farmer undergoes surplus, the farmer income is bigger than the outcome. If it has value same as 100 means the farmers undergo same state, farmer income is as same as the outcome. Besides, if it has value above 100 means the farmers undergo deficit, the farmer's income is smaller than the outcome. It is a measurement of exchange capability from some products which is produced by farmers in rural area with needed product from farmers either it is for productive process or household consumption. The number which lies in farmer exchange rate is a competitive agricultural product with the other product.

\section{Agricultural Productivity}

Productivity terms in the economy is a ratio between input and output (Rutkauskas \& Paulaviciene, 2005) so the productivity commonly can be written such as follows:

$$
\text { Productivity }=\frac{\text { Output }}{\text { Input }}
$$

The analysis of agricultural productivity can be done with 2 approaches namely with partially productive counting (production per hectare) and with total factor productivity where TFP is a skill from all inputs in generating output a whole (Tien, 2011). The agricultural productivity increasing is affected by optimally productive factor usage.

\section{Agricultural Land Conversion}

The conversion of extensively agricultural land is affected by 2 things namely there is agricultural land usage conversion and molding the new land, so the agricultural land's large in a previous year added to the molding of new agricultural land declined by agricultural land usage, so it can be formulated such as follow (Ilham et al., 2005):

$$
\begin{aligned}
& \mathrm{Lt}=\mathrm{Lt}-1+\mathrm{Mt}-\mathrm{Ct} \\
& (\mathrm{Mt}-\mathrm{Ct})=\mathrm{Lt}-\mathrm{Lt}-1
\end{aligned}
$$

Where:

Lt : the wide of land in year $t$

Lt-1 : the wide of land previously (Ha)

Mt : new agricultural land molding in year $\mathrm{t}(\mathrm{Ha})$

$\mathrm{Ct}$ : the conversion of agricultural land usage in years $\mathrm{t}(\mathrm{Ha})$

If agricultural land conversion score is positive means that the broad of agricultural land molding is bigger than agricultural land usage conversion or it can be happened if molding is in the agricultural land only. If agricultural land 
conversion score is negative means that agricultural land conversion score is bigger than new agricultural land molding or it just happened in agricultural land usage conversion only.

\section{Labor in Agricultural Sector}

According to Constitution Number 13 of 2013 about employment mentions that the labor is everyone which capable to do some jobs in order to generate the stuff and service both it fulfills their own needs or for society. Labor is one factor of production which is important besides land and capital. The labor market is affected by the power of supply and demand in labor market toward the labor, where the supply and demand in labor market show the relations between wage and the total amount of laborer. Curve shift of labor demand is affected by some factors including the productive result price, the change of technology and the offering of other production factors, meanwhile, the curve shift of labor supply is affected by the taste change, chance change alternative and immigration (Mankiw, 2011).

The agricultural sector in laborer is a labor which works in the agricultural sector. Agriculture according to BPS (2015) is all activity which related to the existing food plant commodity, estate, forestation and animal husbandry and fishery which is done simply and traditionally, where the laborer in agricultural sector works in some agricultural sub-sectors.

\section{METHOD}

This research will use the descriptive quantitative method. On this research, the researcher will take observation toward 33 provinces in Indonesia (except North Kalimantan), on time period year 2009 up to 2013. The method used is by path analysis, with variables as stated by farmer exchange rate, agricultural land conversion, agricultural poverty also agricultural laborer and agricultural productivity as intervening variables. The data source used on this research is taken from BPS and the minister of agriculture. The path analysis determined on this research can be seen from the graphic below:

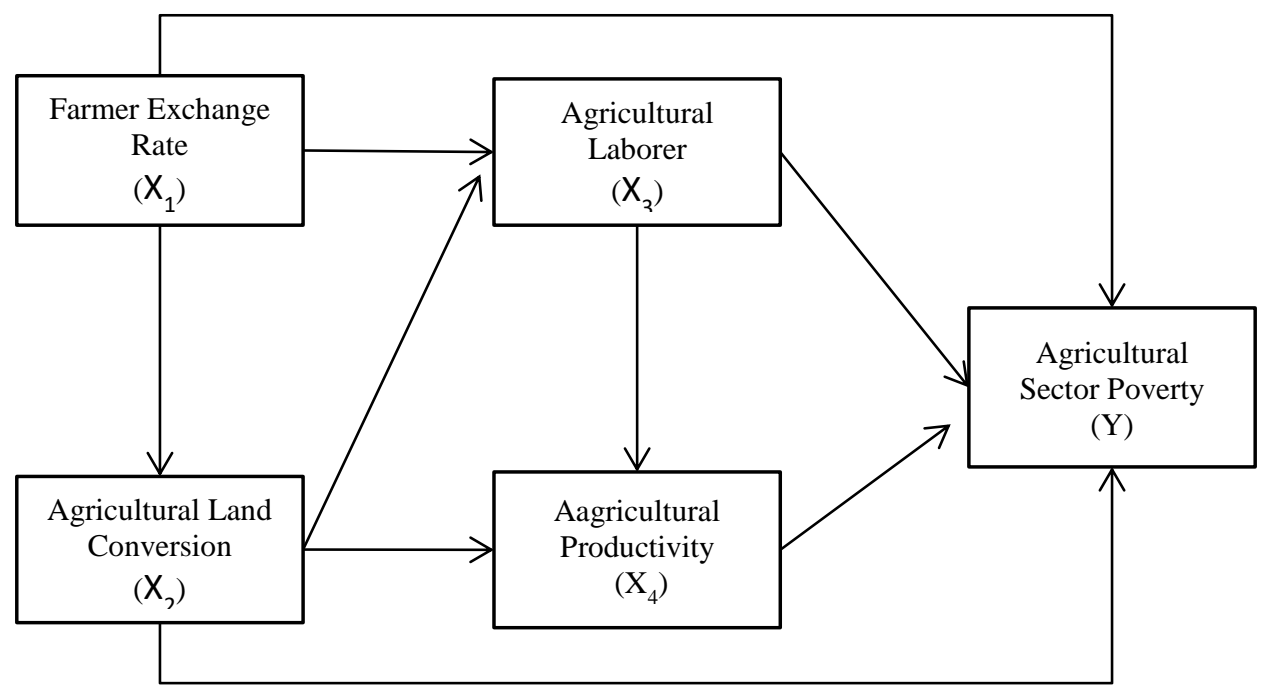

Figure 1. Path Analysis Model 
Model regression of path analysis can be formulated such as follows:

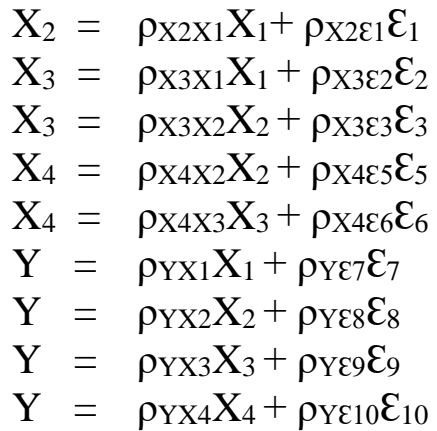

Where:

$\mathrm{Y} \quad$ : agricultural sector poverty (\%)

$\mathrm{X}_{1} \quad$ : farmer exchange rate

$\mathrm{X}_{2}$ : agricultural land conversion (hectare)

$\mathrm{X}_{3} \quad$ : agricultural laborer (soul)

$\mathrm{X}_{4} \quad$ : agricultural productivity (ton/hectare)

$\rho \quad$ : variable coefficient

$\varepsilon \quad$ : residual

\section{RESULT AND DISCUSSION}

After obtained the result from regression analysis, the next step is to do trimming, it will take out the correlation between all variables which is not significant so it is not enclosed back into the path. According to the regression result, so there are some relations between variables which is not significant namely the relation between conversion of agricultural land toward the amount of labor in the agricultural sector and the relation between agricultural land conversion toward poverty in the agricultural sector. Path diagram after trimming can be seen as below:

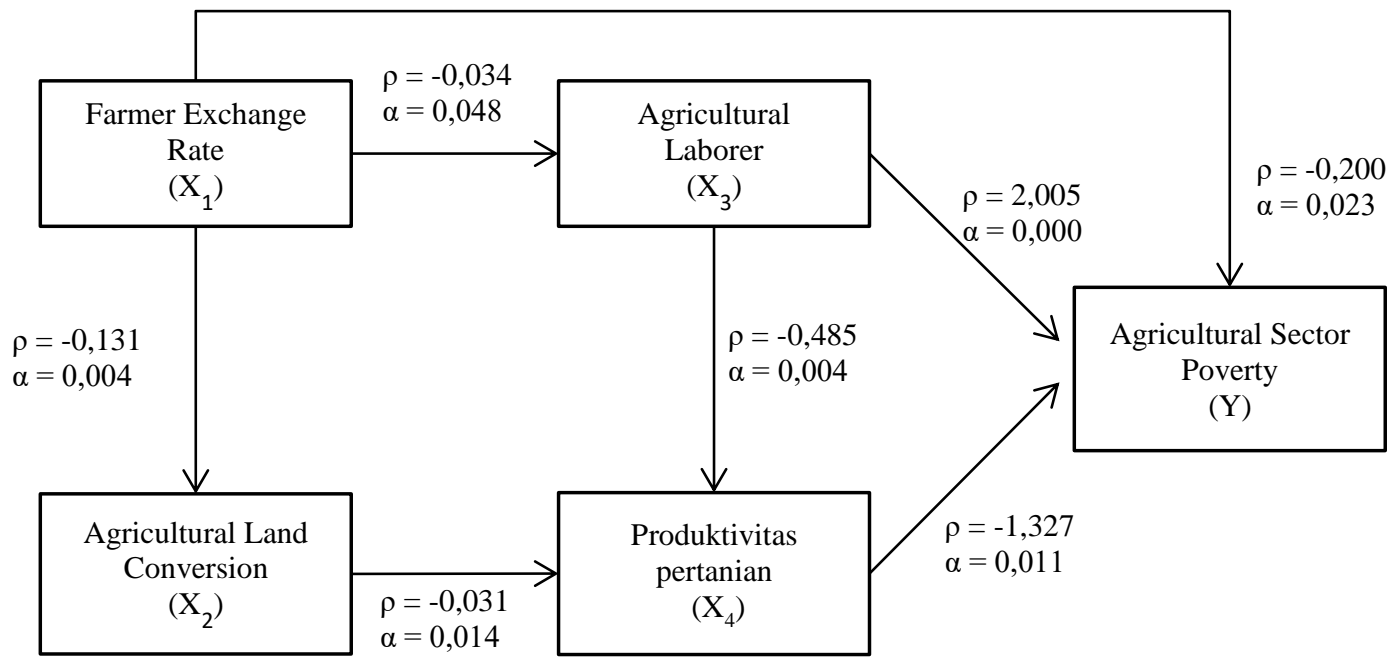

Figure 2. Path diagram after trimming 


\section{Direct Effect and Indirect Effect of Farmers Exchange Rate and Agricultural Land Conversion Toward Agricultural Sector Poverty}

Based on path analysis after trimming, it can be calculated in its direct effect and indirect among variables such as follows:

1. The direct effect of farmer exchange rate $\left(X_{1}\right)$ toward agricultural sector poverty (Y) is:

$\rho \mathrm{YX}_{1}=-0,200$

2. The indirect effect of farmer exchange rate $\left(X_{1}\right)$ through agricultural land conversion $\left(\mathrm{X}_{2}\right)$ and agricultural productivity $\left(\mathrm{X}_{4}\right)$ toward agricultural sector poverty (Y) is:

$\rho \mathrm{X}_{2} \mathrm{X}_{1} \cdot \rho \mathrm{X}_{4} \mathrm{X}_{2} \cdot \rho \mathrm{YX}_{4} \quad=\quad-0,131 \mathrm{x}-0,031 \mathrm{x}-1,327$

$$
=-0,005
$$

3. The indirect effect of farmer exchange rate $\left(X_{1}\right)$ through agricultural laborer $\left(\mathrm{X}_{3}\right)$ and agricultural productivity $\left(\mathrm{X}_{4}\right)$ toward agricultural sector poverty $(\mathrm{Y})$ is:

$$
\begin{aligned}
\rho \mathrm{X}_{3} \mathrm{X}_{1} \cdot \rho \mathrm{X}_{4} \mathrm{X}_{3} \cdot \rho \mathrm{YX}_{4} & =-0,034 \times-0,485 \times-1,327 \\
= & -0,022
\end{aligned}
$$

4. The indirect effect of farmer exchange rate $\left(\mathrm{X}_{1}\right)$ through agricultural laborer $\left(\mathrm{X}_{3}\right)$ toward agricultural sector poverty $(\mathrm{Y})$ is:

$$
\begin{aligned}
\rho \mathrm{X}_{3} \mathrm{X}_{1} \cdot \rho \mathrm{YX}_{3} & -0,034 \times 2,005 \\
& =-0,068
\end{aligned}
$$

5. Effect total of farmer exchange rate $\left(\mathrm{X}_{1}\right)$ toward agricultural sector poverty $(\mathrm{Y})$ is:

$$
\begin{aligned}
\left(\rho \mathrm{YX}_{1}\right)+\left(\rho \mathrm{X}_{2} \mathrm{X}_{1} \cdot \rho \mathrm{X}_{4} \mathrm{X}_{2} \cdot \rho \mathrm{YX}_{4}\right)+ & \left(\rho \mathrm{X}_{3} \mathrm{X}_{1} \cdot \rho \mathrm{X}_{4} \mathrm{X}_{3} \cdot \rho \mathrm{YX}_{4}\right)+\left(\rho \mathrm{X}_{3} \mathrm{X}_{1} \cdot \rho \mathrm{YX}_{3}\right) \\
+\left(\rho \mathrm{X}_{4} \mathrm{X}_{1} \cdot \rho \mathrm{YX}_{4}\right) & =-0,200+-0,005+-0,022+-0,068 \\
= & -0,097
\end{aligned}
$$

6. The indirect effect of agricultural land conversion $\left(\mathrm{X}_{2}\right)$ through agricultural productivity $\left(\mathrm{X}_{4}\right)$ toward agricultural sector poverty $(\mathrm{Y})$ is :

$$
\begin{aligned}
\rho \mathrm{X}_{4} \mathrm{X}_{2} \cdot \rho \mathrm{YX}_{4} & =-0,031 \times-1,327 \\
& =0,041
\end{aligned}
$$

Based on the result, the model can be interpreted as below :

1. Farmer exchange rate $\left(X_{1}\right)$ is directly has a negative effect toward agricultural sector poverty $(\mathrm{Y})$ which reaches $-0,2$. It means that if farmer exchange increased by unit per unit, so it will decrease the rate of agricultural sector poverty which reaches 0,2 per unit.

2. Farmer exchange rate $\left(X_{1}\right)$ through agricultural land conversion $\left(X_{2}\right)$ and agricultural productivity $\left(\mathrm{X}_{4}\right)$ indirectly has negative effect toward agricultural sector poverty $(\mathrm{Y})$ which reaches $-0,005$. It means that if farmer exchange rate increased by unit per unit, so it will decrease the rate of agricultural sector poverty which reaches 0,005 per unit

3. Farmer exchange rate $\left(X_{1}\right)$ through agricultural laborer $\left(X_{3}\right)$ and agricultural productivity $\left(\mathrm{X}_{4}\right)$ indirectly has negative effect toward agricultural sector poverty (Y) which reaches $-0,022$. It means that if farmer exchange rate increased by unit per unit, so it will decrease the rate of agricultural sector poverty which reaches 0,022 per unit.

4. Farmer exchange rate $\left(X_{1}\right)$ through agricultural laborer $\left(X_{3}\right)$ indirectly has negative effect toward agricultural sector poverty $(\mathrm{Y})$ which reaches $-0,068$. It 
means that if farmer exchange rate increased by unit per unit, so it will decrease the rate of agricultural sector poverty which reaches 0,068 per unit

5. Farmer exchange rate $\left(X_{1}\right)$ directly has negative effect toward agricultural sector poverty $(\mathrm{Y})$ which reaches $-0,420$. It means that if farmer exchange rate increased by unit per unit, so it will decrease the rate of agricultural sector poverty which reaches 0,420 per unit.

6. Farmer exchange rate $\left(\mathrm{X}_{1}\right)$ through agriculture productivity $\left(\mathrm{X}_{4}\right)$ indirectly has negative effect toward agricultural sector poverty (Y) reaches 0,041 . It means that if farmer exchange rate increased by unit per unit, so it will decrease the rate of agricultural sector poverty which reaches 0,041 per unit.

Farmer exchange rate is an index between the price received by farmers and the price paid by farmers, can be used as a measure of real income farmers (Syekh, 2013). According to the poverty theory proposed by Nurske in Kuncoro (2010) states that low income will affect the low level of investment, in this case, agricultural land is one of the investments owned by farmers. The result of the path analysis is also in accordance with the research of Syekh (2013) stating that basically, farmer exchange rate will be a driver for farmer's performance to do farming business so that with the increasing farmer exchange rate, it will be able to improve farmer's prosperity. In accordance with the results of path analysis obtained that the conversion of agricultural land indirectly through agricultural productivity have a significant positive effect on agricultural poverty. This is in line with Danapriatna \& Panuntun research (2013) which found that conversion of agricultural land negatively affects farmers' welfare. Barbier \& Hochard (2016) also found that the degradation of agricultural land will affect the increase in poverty.

Based on the result analysis, it can be obtained that the decline of the agriculture sector poverty rate in Indonesia can be done by increasing the farmer exchange rate, increasing the agricultural productivity and declining the agricultural land conversion. The increasing of farmer exchange rate has bigger effect toward the declining of agricultural sector poverty than agricultural land conversion declining.

\section{CONCLUSION}

According to the analysis result and the discussions, so from this research, it can be concluded that: Farmer exchange rate directly effects significantly negative toward agricultural sector poverty. Farmer exchange rate through agricultural land conversion and agricultural productivity is indirectly has a significantly negative effect toward agricultural sector poverty. Farmer exchange rate through agricultural laborer and agricultural productivity indirectly has significantly negative effect toward agricultural sector poverty. Farmer exchange rate through agricultural laborer is indirectly had significantly negative effect toward agricultural sector poverty. It involves the meaning that the increasing farmer exchange rate will decrease agricultural sector poverty. Agricultural land conversion through agricultural productivity indirectly has significantly positive effect toward agricultural sector poverty. It involves the meaning that the increasing agricultural land conversion will increase agricultural sector poverty.

Some suggestion which is used to increase farmer exchange rate, decrease agricultural land conversion and increase agricultural productivity to decrease 
agricultural sector poverty in Indonesia can be formulated such as follows: The increasing of agricultural product price can increase farmer exchange rate, relating to this, so the governments has role in price guarantee of agricultural products. The increasing price of the agricultural product can be done if the agricultural product has export competitive value, so it needs to be done by increasing the quality with export competitive. As an effort to increase agricultural productivity, so it needs to be done the increasing of total production of agricultural result. The increasing of total production in agricultural result can be increased by the improvement of human resources quality, by doing training and acknowledging the new technology toward farmers, and doing intensively training from professional labor to each farmers group in rural area. The development of ultimate seeds can help farmers to increase the total production maximally, so it can increase the total production which will affect to farmer exchange rate and their productivity. The agricultural land conversion control can be done with strengthening the rule for land conservation in agricultural sector, mainly for the land which is high in quality and still productive. The preparation of maximally land by taking attention toward land productivity and high quality in land molding program, it can increase the progress of agricultural productivity.

\section{REFERENCES}

Bappenas. (2014). Analisis Nilai Tukar Petani (NTP) Sebagai Bahan Penyusunan RPMJN 2015-2019. Jakarta

Bappenas. (2014). Studi Pendahuluan: Rencana Pembangunan Jangka Menengah Nasional (RPJMN) Bidang Pangan dan Pertanian 2015-2019. Jakarta

BPS. (2016). Tenaga Kerja. Retrieved from https://www.bps.go.id/linkTabel Statis/view/id/970

BPS. (2015). Indikator Kesejahteraan Rakyat 2015. Jakarta

BPS. (2015). Luas Lahan Menurut Penggunaan 2014. Jakarta

BPS. (2015). Nilai Tukar Petani. Retrieved from http://www.bps.go.id/link Tabel Statis/view/id/1482.

BPS. (2014). Data dan Informasi Kemiskinan Kabupaten/Kota 2013. Jakarta

BPS. (2014). Keadaan Angkatan Kerja di Indonesia November 2013. Jakarta

BPS. (2014). Keadaan Angkatan Kerja di Indonesia Agustus 2014. Jakarta

BPS. (2013). Data dan Informasi Kemiskinan Kabupaten/Kota 2012. Jakarta

Barbier, E. B., \& Hochard, J.P. (2016). Does Land Degradation Increase Poverty in Developing Countries? Plos One Journal, 11(5). https://doi.org/ 10.1371/journal.pone.0152973.

Damayanthi, V.R. (2008). Pengaruh Alih Guna Lahan Pertanian Terhadap Tenaga Kerja Sektor Pertanian, Produktivitas Sektor Pertanian dan Struktur Perekonomian Kota Batu. Tesis. Program Studi Magister Ilmu Ekonomi. Pascasarjana Fakultas Ekonomi Universitas Brawijaya

Danapriatna, N., \& Panuntun, Y.U. (2013). Pengaruh Konversi Lahan Pertanian Terhadap Tingkat Kesejahteraan Petani (Kasus di Kecamatan Setu, Kabupaten Bekasi). CEFARS: Jurnal Agribisnis dan Pengembangan Wilayah, 4(2), 1-10.

Hasanuddin, T., Trully, D., \& Endaryanto, T. (2009). Akar Penyebab Kemiskinan Petani Hortikultura di Kabupaten Tanggamus, Propinsi Lampung. Jurnal Agrikultura, 20(3) 164-170. 
Ilham, N., Syaukat, Y., \& Friyatno, S. (2005). Perkembangan dan Faktor-faktor yang Mempengaruhi Konversi Lahan Sawah serta Dampak Ekonominya. Jurnal Socio-Economic of Agriculture and Agribusiness, 5(2) 1-25.

Kuncoro, M. (2010). Dasar-Dasar Ekonomika Pembangunan Edisi Kelima. UPP STIM YKPN. Yogyakarta.

Mankiw, G. N. (2011). Principles of Economics. Pengantar Ekonomi Mikro. Jakarta: Salemba Empat.

Munir, M. (2008). Pengaruh Konversi Lahan Pertanian Terhadap Tingkat Kesejahteraan Rumah Tangga Petani (Kasus : Desa Candimulyo, Kecamatan Kertek, Kabupaten Wonosobo, Provinsi Jawa Tengah). Skripsi. Program Studi Komunikasi dan Pengembangan Masyarakat, Fakultas Pertanian Institut Pertanian Bogor.

Nugroho, I., \& Dahuri, R. (2012). Pembangunan Wilayah: Perspektif Ekonomi, Sosial dan Lingkungan. Edisi Kedua. LP3ES. Jakarta.

Rutkauskas, J., \& Paulavičiene, E. (2005). Concept of productivity in service sector. Engineering Economics, 43(3), 35-41.

Sadikin, I., \& Subagyono, K. (2008). Kinerja Beberapa Indikator Kesejahteraan Petani Padi Di Perdesaan Kabupaten Karawang 2008. Bandung: Balai Pengkajian Teknologi Pertanian Jawa Barat.

Syekh, S. (2013). Peran Nilai Tukar Petani dan Nilai Tukar Komoditas dalam Upaya Peningkatan Kesejahteraan Petani Padi di Provinsi Jambi. Jurnal Bina Praja: Journal of Home Affairs Governance, 5(4), 253-260.

Tien, T. (2012). Analisis Efisiensi Teknis Usahatani Padi Sawah Aplikasi Pertanian Organik (Studi Kasus Di Desa Sumber Ngepoh, Kecamatan Lawang) Kabupaten Malang MT 2009-2010. el-Hayah, 1(4) 182-191. 